
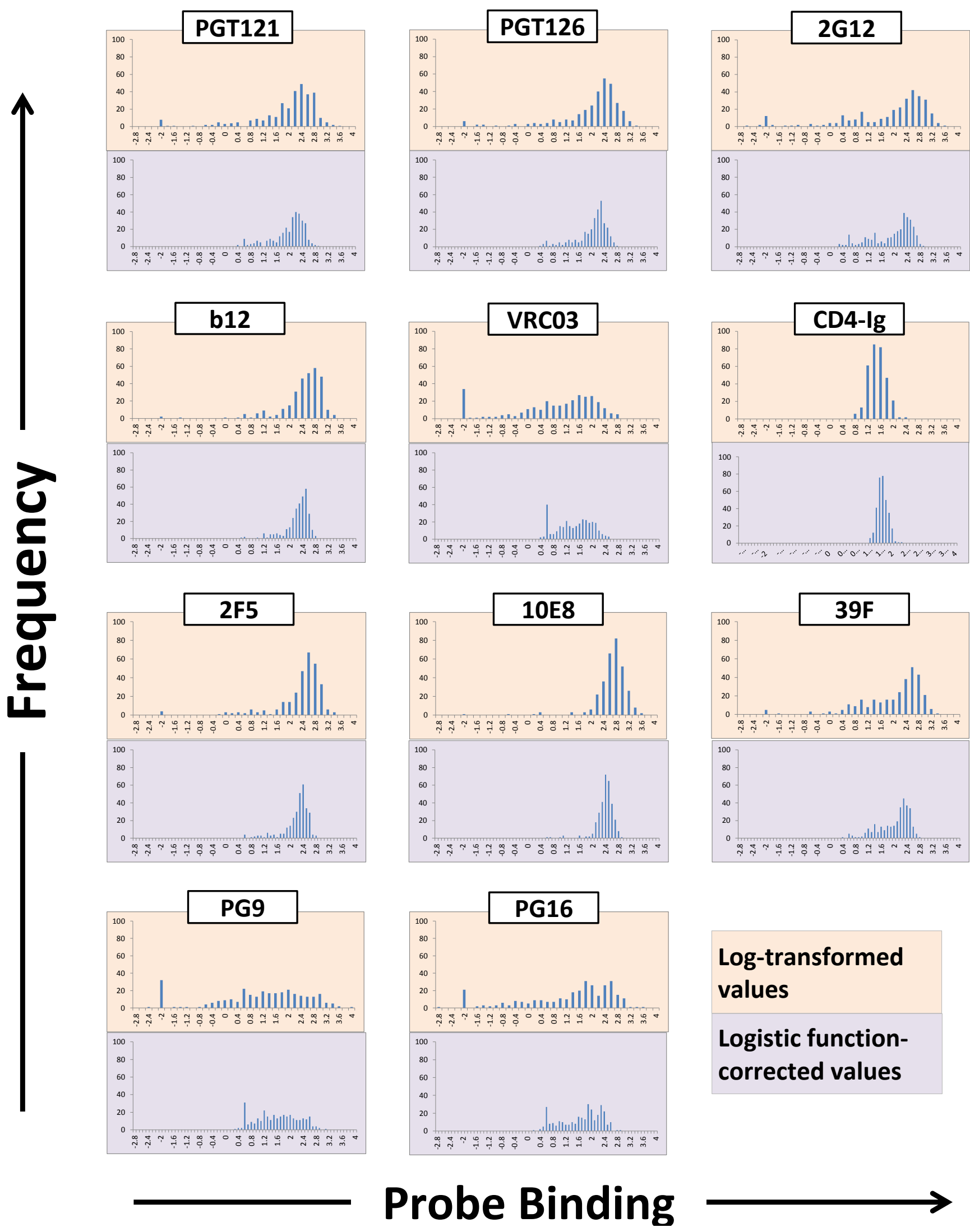

\title{
Log-transformed values
} Logistic functioncorrected values

\section{Probe Binding}

